\title{
Dhole pack size variation: Assessing effect of Prey availability and Apex predator
}

\author{
Aishwarya Bhandari ${ }^{1}$, Pallavi Ghaskadbi ${ }^{1}$, Parag Nigam ${ }^{1}$, and Bilal Habib ${ }^{2}$ \\ ${ }^{1}$ Affiliation not available \\ ${ }^{2}$ Wildlife Institute of India
}

July 21,2020

\begin{abstract}
Ecosystems wherein social and solitary predators share space, complex asymmetric intraguild interactions actively shape the group size of social carnivores. Intense intraguild predation has been known to result in reduced group size and low recruitment rates in subordinate social carnivores. In South and South-east Asia, Dhole, tiger and leopard form a widely distributed sympatric guild of large carnivores. In this paper we attempted to understand the pack size dynamics of a subordinate social predator, the dhole, by investigating factors underlying pack size variation at two neighbouring sites. We further evaluated our local-scale patterns of pack size variation at a larger scale by doing a distribution-wide assessment of pack size across dhole ranging countries. Across study sites, we found an inverse relationship between the local abundance of a top predator and group size of a subordinate predator while accounting for variability in resources and habitat heterogeneity. Tiger density was low $(0.71 / 100 \mathrm{Km} 2)$ at the site having large dhole packs $(16.8 \pm 3.1)$ whereas, a relatively smaller average dhole pack size (6.4 \pm 1.3$)$ was observed in a higher tiger density $(5.67 / 100 \mathrm{Km} 2)$ area. Our results on distribution-wide assessment are concurrent with local-scale results, showing a positive association between prey abundance and pack size and a negative association between tiger densities and dhole pack size. Our study takes us one step closer to trying to answer the age-old question of what drives the pack size of social predators in a multi-predator system. Linking behaviour to population dynamics and carnivore interactions is another highlight of the study. Often helpful while optimizing conservation triage and formulation of management implications like recovery and translocations.
\end{abstract}

\section{Introduction}

In the past few decades, there has been a shift in wildlife biology studies from single species targeted approach to ecosystem conservation approach (Linnell \& Strand, 2000). This holistic approach reveals how interspecific interactions can alter community structures and ecosystem functioning (Ford \& Goheen, 2015). One such interaction is intraguild competition among large carnivores that shape the predatory guild (Palomares \& Caro, 1999). Often considered as keystone species in the terrestrial ecosystems (Caro \& O'Doherty,1999), ecological effects of large carnivores extend down to herbivores and plants (Ritchie \& Johnson, 2009) thereby structuring ecosystems along multiple food web pathways. Therefore, safeguarding of viable large carnivore populations is essential for ecosystem equilibrium, that cannot be ensured without understanding their demographic responses to each other.

Over the years, it has been established that competition among predators can be direct or indirect (Case \& Gilpin, 1974; Macdonald, 1983; Crooks \& Soule, 1999; Ritchie \& Johnson, 2009; Letnic, Ritchie, \& Dickman, 2012). The indirect form is termed as exploitative competition (Case \& Gilpin, 1974). Wherein resources are harvested disproportionately by one predator and are not available for other competing predators (Vance, 1984). This type of interaction is mostly unidirectional with larger body sized carnivores i.e. apex predators (Ordiz, Bischof, \& Swenson, 2013), dominating the guild. Evolutionarily, competitively subordinate carnivores have adapted to exploitative competition by opting for differential life-history strategies like group 
living, reduced overlap in diet, Spatio-temporal activity and habitat use (Creel \& Creel,1996; Durant, 2000; Creel, 2001; Durant, 2002).

On the other hand, interference interaction is a rather direct form of competition in the predatory guild (Vance,1984). Some manifestations of interference competition are interspecific territoriality, kleptoparasitism and direct killing (Linnell \& Strand, 2000). However, interference competition is not easy to demonstrate, because it is multifaceted and involves an array of factors acting along, such as anthropogenic disturbance, alterations in community structure of prey and other predators and the overall productivity of ecosystems (Greenville, Wardle, Tamayo, \& Dickman, 2014; Newsome \& Ripple, 2015; Swanson et al., 2014). Therefore, there is a dearth of theoretic and practical understanding of interference competition because of the lack of replicability of such 'natural experiments' (Linnell \& Strand, 2000).

Most of our understanding on intraguild competition comes from studies on exploitative competition, although interference competition is critical in multi-predator systems and is always functioning in the background (Periquet, Fritz, \& Revilla, 2015). Shreds of evidence from classic ecology studies indicate that subordinate predator experience low recruitment rates and even face extirpations in a high apex predator density scenario (Carbyn, Armbruster, \& Mamo, 1994; Clark, 1994; Lindström, Brainerd, Helldin, \& Overskaug, 1995; Henke \& Bryant, 1999). However, an inverse pattern is observed when interference competition is removed. A recent continent-wide review shows expansion of golden jackals (Canis aureus) as a response to grey wolf (Canis lupus ) exterminations in Europe due to persecution by humans. (Krofel, Giannatos, Cirovic, Stoyanov, \& Newsome, 2017). Ecosystems wherein social and solitary predators share space, intraguild competition often shape trends of group sizes in social carnivores. The group size of subordinate predators such as African wild dogs (Lycaon pictus) (Creel \& Creel,1996; Creel \& Creel, 1998), Spotted hyenas (Crocuta crocuta) (M'soka, Creel, Becker, \& Droge, 2016) and cooperative breeding mongooses (Suricata suricata ) (Clutton-Brock et al., 1999) have been studied to be inversely related to lion densities, over temporal and spatial scales.

One such sympatric guild of solitary and social carnivores, found in South-east Asian forests is of tiger (Panthera tigris), dhole (Cuon alpinus) and leopard (Panthera pardus). Tigers are considered to be top predators whereas dhole and leopard are intermediate predators, forming an asymmetric guild (Steinmetz, Seuaturien, \& Chutipong, 2013). In the Indian subcontinent dholes have been widely studied along with tigers and leopards, to understand sympatric interactions among the three carnivores (Acharya, 2007; Johnsingh,1992; Karanth \& Sunquist, 2000; Wang \& Macdonald, 2009; Wegge, Odden, Pokharel, \& Storaas, 2009; Steinmetz, Seuaturien, \&, Chutipong, 2013; Rayan \& Linkie, 2016). Competition between these carnivores is likely because of the high overlap in diet spectrum (Karanth \& Sunquist, 1995). Prey rich forests facilitate sympatry between the carnivores (Karanth \& Sunquist, 2000; Wang \& Macdonald, 2009; Karanth, 2017). Studies in sub-optimal habitat conditions with scarce resources have shown evidence of intraguild predation among the sympatric carnivores (Steinmetz, Seuaturien, \&, Chutipong, 2013; Rayan \& Linkie, 2016). Conversely, tiger depleted systems have shown a significant increase in dhole site occupancy (Steinmetz, Seuaturien, \& Chutipong, 2013; Rasphone, Kery, Kamler, \& Macdonald, 2019).

Pack size, however, is a vital aspect and considered to be a function of population size in social predators (Fernandez et al., 2020) but it remains unaddressed for the dhole. So far, we have no long-term studies to assess and understand various ecological factors that determine group size dynamics of dhole, as seen in case of other subordinate social predators (Periquet, Fritz, \& Revilla, 2014; Green, Farr, Holekamp, Strauss \& Zipkin, 2019).

We observed a significant variation in pack size of dholes at the two neighbouring protected areas having similar ecological settings, Tadoba Andhari Tiger Reserve and Navegaon Nagzira Tiger Reserve in the Central Indian Landscape, Maharashtra, India and attempted to investigate factors underlying this variation in pack size of dholes. Group size variation is a crucial characteristic of carnivore sociality (Macdonald,1983) and is an attribute of differential ecological settings over temporal and spatial scale (Markham, Gesquiere, Alberts, \& Altmann, 2015). Largely governed by co-predator density and prey abundance (Gusset \& Macdonald, 2010). Furthermore, availability of habitat, topography and habitat features elicit prey distribution and 
encounter rate at a given place and time (White \& Garrott, 2005; Fedriani, Fuller, Sauvajot, \& York, 2000).

After investigating factors linked with pack size variation of dholes at the two reserves, we further elucidate our local scale patterns at a wider scale by doing a distribution-wide assessment of pack size across dhole ranging countries. 1. Hypothesis: High apex predator density negatively affects pack size of subordinate carnivores (Groom, Lannas, \& Jackson, 2017). Prediction: Areas with higher tiger density will show smaller pack sizes and vice-versa. 2. Hypothesis: When tiger density are low pack sizes are determined by prey abundance. Prediction: Dhole pack size will positively correlate to higher prey abundance. 3. Hypothesis: Terrain ruggedness influences pack size as dholes are cursorial predators (White \& Garrott, 2005). Prediction: Areas with high ruggedness will correspond to low pack sizes and vice-versa.

\section{Methods and Materials:}

\subsection{STUDY AREA}

The study was primarily conducted at two neighbouring sites in the Eastern Vidarbha Tiger Landscape within the greater Central Indian Tiger Landscape. The Two sites were; the Tadoba Andhari Tiger Reserve (TATR) and Navegaon Nagzira Tiger Reserve (NNTR) (Figure 1). TATR (19.95428 E to 20.51695 E and $79.12749 \mathrm{~N}$ to $79.73494 \mathrm{~N}$ ) is $625 \mathrm{~km} 2$ and NNTR (20.86209 E to $21.44738 \mathrm{E}$ and $79.69802 \mathrm{~N}$ to $80.39064 \mathrm{~N}$ ) is $656 \mathrm{~km} 2$ (core) in area. Both the study sites are in the Deccan Plateau zone according to the biogeographic classification of India (Rodgers \& Panwar, 1988) and are located at a distance of $\sim 85 \mathrm{~km}$ from each other. The study sites experience subtropical climate with three distinct seasons- summer, monsoon, and winter. The Reserves receive southwest monsoons with rainfall (1100-1500 mm) persisting from June to September. The Forest type is Southern tropical dry deciduous (Champion \& Seth, 1968). Teak (Tectona grandis) is the dominant species followed by Terminalia tomentosa and Lagerstroemia parviflora in the study sites. The terrain type is mostly plain with shallow valleys and rounded hills. Tiger, leopard and dhole form the major predatory guild in the study sites and chital (Axis axis), sambar (Rusa unicolor), nilgai (Boselaphus tragocamelus), wild pig (Sus scrofa), gaur (Bos gaurus), barking deer (Muntiacus muntjac) are the major prey species (Dhanwatey et al., 2013).

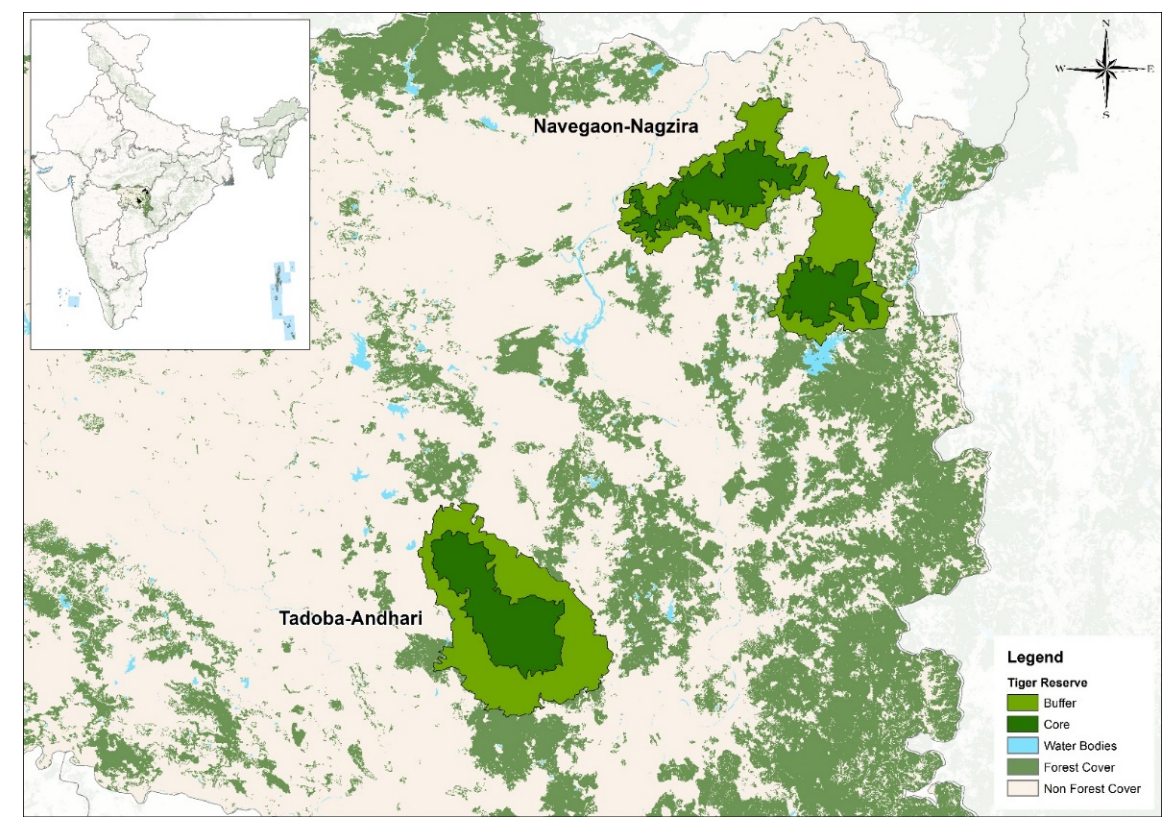

Figure 1. Map showing Tadoba Andhari Tiger Reserve and Navegaon NagziraTiger Reserve in Eastern Vidarbha Landscape. Inset showing study area location in the map of India. 


\section{2 .) Field and Analytical method: Dhole pack size variation across study sites}

In field studies individual identification of dholes is challenging because of their uniform pelage pattern (Modi, Habib, Ghaskadbi, Nigam, \& Mondol, 2019), therefore we adhered to pack identification on the basis of activity centres (Stansbury et al., 2014). We surveyed study sites through camera trapping and identified activity centres on the basis of pack's activity hotspots and concentrated indirect signs. The understnading of movement patterns from telemetry study at our study sites suggests that the core home range/ activity centres for dhole pack ranges from $1 \mathrm{~km}^{2}$ to $11 \mathrm{~km}^{2}$ i.e. the area exclusive to a pack's territory (Ghaskadbi et al. Unpublished). Therefore, based on our observations of activity hotspots, sightings of packs were only recorded at their activity hotspots. The sightings at overlapping pack boundaries were not included to avoided confusion between the packs.

\section{3. a) Field and Analytical method: Variation in prey composition and density across study sites}

Line transect based distance sampling (Buckland et al., 2001) was used to estimate prey densities at the two sites. Line transects were laid in a stratified random framework to ensure spatial coverage of all vegetation types. All transects were of $2 \mathrm{~km}$ length. Survey effort of $950 \mathrm{~km}$ and $984 \mathrm{~km}$ was put in TATR and NNTR, respectively. Data for species, group size and composition, GPS (global positioning system) location of every observation, bearing of the animal using compass and angular sighting distance using laser range finders, was recorded whenever sightings were made online transects.

\section{b) Estimation of ungulate species across study sites}

Individual density of all the species was calculated using Distance program version 6.2 (Thomas et al., 2010). We first examined the data from both sites for each species separately. Following this, the species observations at distances beyond which sightings were almost none was dropped or observations were binned to achieve model fit. Akaike Information Criterion and goodness-of-fit (GOF-p) tests were used to judge and the fit of the model. Based on the selected model, individual density ( $\hat{\mathrm{Di}}$ ) and estimates of group density $(\hat{\mathrm{Dg}})$ were derived for each species.

\section{4. a) Field and Analytical method: Variation in tiger density across study sites}

Capture-recapture based camera trapping was done to estimate densities of carnivores following standard protocols (Karanth \& Nichols., 1998). A grid size of $2 \mathrm{~km}^{2}$ was used for camera trap placement. Based on the sign survey, camera traps were stationed on both sides of the trails, at junctions and water sources to maximize photo captures (Karanth \& Nichols., 1998). Distance between the camera stations was between 1 $\mathrm{km}$ to $1.5 \mathrm{~km}$ to ensure spatial coverage in the sampling area and capture probability of the study population (Pollock, Nichols, Brownie, \& Hines, 1990). A closing period of 30 days ( $\mathrm{n}=9144$ in TATR and $\mathrm{n}=13440$ in NNTR Trap nights) was kept to ensure demographic closure.

\section{b) Density estimation of Tiger across study sites:}

Using photo captures, tiger density was estimated in SECR framework using maximum likelihood approach (Borchers \& Efford, 2008). The analysis was carried out in program R (3.5.3) (R Core Team, 2013) using package "secr" (3.2.1) (Efford \& Efford, 2019). In SECR, we laid a buffer of $7 \mathrm{~km}$ based on spatial scale detection $(\sigma)$ around our camera trap matrix. The best-fit model based on the lowest AIC value was then selected for density $(\hat{D})$, capture probability at activity center (go), and spatial scale of detection $(\sigma)$.

\section{5. a) Data sources for distribution-wide assessment of dhole pack size:}

Through google scholar we searched for scientific literature on pack size of dholes, using the keywords "Cuon alpinus", "Dhole", "Average", "Mean", "Pack-size". Our search resulted in 34 scientific assessments from 1973 to 2018 that had reported average pack size of dholes. These 34 assessments belonged to 24 unique protected areas across dhole ranging countries in South and South-east Asia. 18 of these unique sites were also a part of the recently published dhole diet review (Srivathsa, Sharma, \& Oli, 2020). Subsequently, snowball sampling approach was used (Handcock \& Gile, 2011), by using dhole pack size as baseline information from 
the previously conducted assessments. Literature cited within these assessments were referred to collate data on tiger density along with prey density (of the closest or same assessment year) and size of the protected area. We obtained data on the topography of 24 protected areas through google earth engine (Gorelick et a., 2017).

\section{b) Analytical methods:}

We used generalized linear models to examine correlates of dhole pack size reported from 24 unique sites across dhole distribution range. We used only those studies $(n=29)$ for which data on all the predictor variables were available i.e., tiger density and ungulate density, size of the protected area (PA), elevational heterogeneity and terrain ruggedness of the PA. We checked for correlations among predictors and dropped the correlated ones $(\mathrm{r}>0.6)$, prior to analysis. After screening for normal distribution of response variable, we used "gaussian" family for the analysis. We tested for model parameters based on our hypothesis, and compared them to null model (Intercept only). Model fits were compared using Akaike's Information Criterion corrected $\left(\mathrm{AIC}_{\mathrm{C}}\right)$, and the effect of parameters was gauged based on direction and statistical significance of corresponding $\beta$-coefficients. We used "MuMIn" package for model selection and averaging. Model selection was based on difference between AIC models, $(\Delta$ AIC $<2)$. Further, model selection was done using Royall's 1/8 strength of evidence and 95\% cumulative weight criteria. Model averaging was carried out for parameters based on top model selection. All analyses were performed in program R ( R Development Core Team, 2014).

\section{Results:}

\subsection{Pack size variation}

\section{Dhole Pack size from TATR and NNTR}

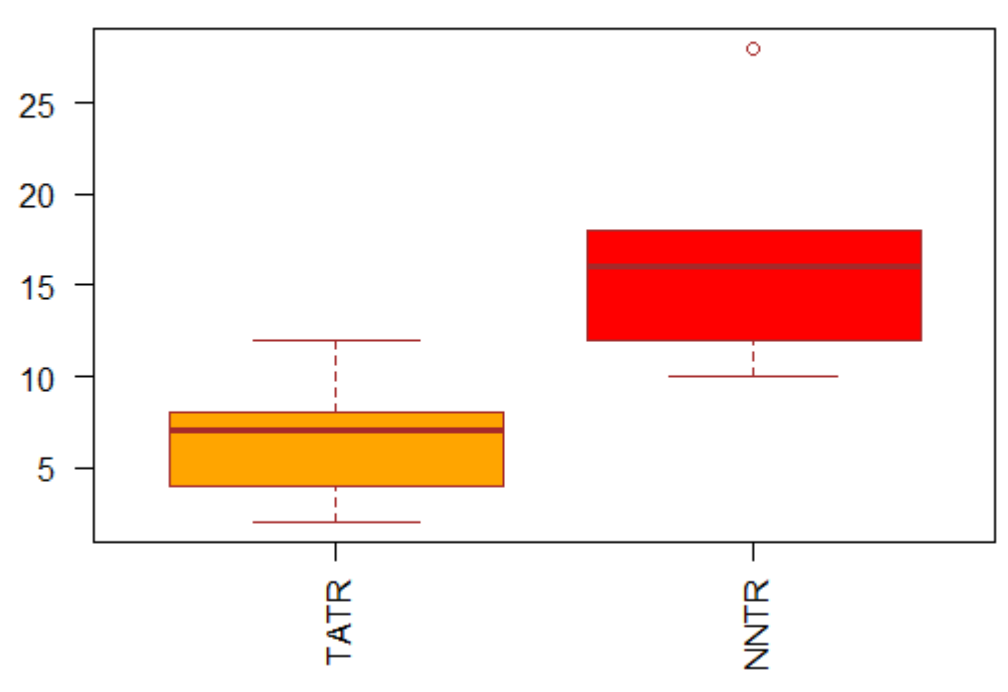

We identified seven packs from TATR and five packs form NNTR based on their exclusive activity hotspots. Number of individuals in a pack ranged from 7 to 12 for TATR Packs and 10 to 28 for NNTR Packs. The reported average pack size was 6.4 (1.3) and 16.8 (3.1) for TATR and NNTR, respectively. A significant difference was found between the pack size of TATR and NNTR $(t=-3.05$, p-value $=0.02)$ (Figure 2).

Figure 2. Comparison of dhole pack size from TATR and NNTR 


\subsection{Prey composition and density across study sites:}

Total prey density per $100 \mathrm{~km}^{2}$ was reported as 16.94 in NNTR and 19.28 in TATR. Major prey species in both the study sites were chital, sambar, nilgai, wild pig, gaur, and barking deer (Table 1). Gaur density was 5.21 (1.41) the highest followed by chital 4.61(1.2) in NNTR. In TATR, the density of chital was the highest 5.10 (1.22) followed by sambar 4.68 (0.76).

\subsection{Large predator density across study sites}

We got 452 photo captures of tigers in TATR and 211 photo captures in NNTR. A total of 71 tigers in TATR and 8 tigers in NNTR were identified through camera trap images. The heterogeneity model with the lowest AIC value was chosen based on difference in gender specific capture rate. Tiger density per $100 \mathrm{~km}^{2}$ was found to be 5.67 (0.69) in TATR. The estimated density per $100 \mathrm{~km}^{2}$ for tiger in NNTR was $0.71(0.24)$. The number of photo captures of dholes was 68 and 689 in TATR and NNTR, respectively.

\subsection{Distribution-wide assessment of dhole pack size:}

We used average dhole pack size as the response variable and tiger density, ungulate density, area of PA, terrain ruggedness as predictor variables. We scaled predictor variables (Size of PA, elevational heterogeneity and terrain ruggedness) and checked for correlation among all predictor variables. We dropped elevational heterogeneity as the predictor variables because of its high correlation with terrain ruggedness. We ran a total of 10 additive and interactive models (Table 2, Figure 3). The top two models achieved the model selection criterion of $\triangle \mathrm{AICc}<2$. Upon model selection we found, additive effect of tiger density and prey density and interactive effect of tiger density and prey density, to be the top two best models (Table 3, Figure $4 \& 5$ ). On averaging the two top models (Table 4, Figure 6) we found a negative association of tiger density $(-0.89 \pm 0.33, \mathrm{p}=0.01)$ and a positive association of prey density $(0.09 \pm 0.03, \mathrm{p}=0.03)$ with the pack size and prey*tiger density $(0.01 \pm 0.0, \mathrm{p}=0.18)$ was not significant but still explained the relation with the response variable.

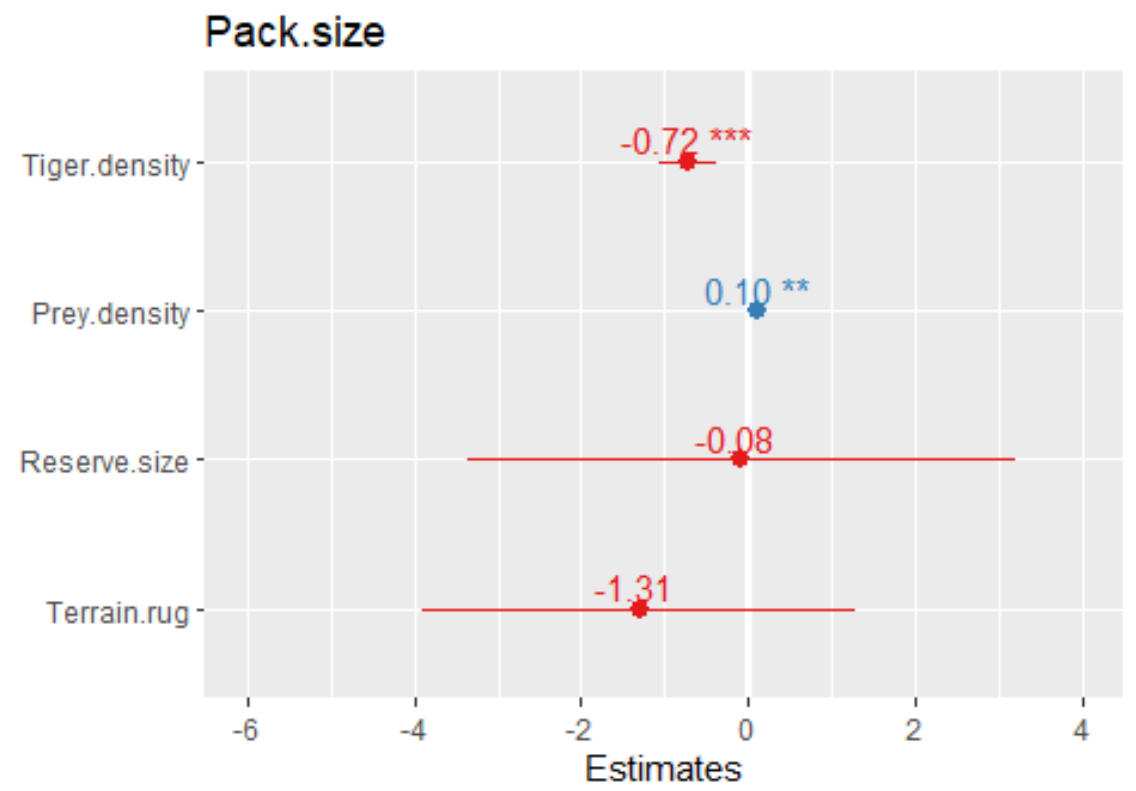

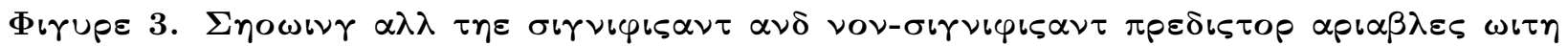

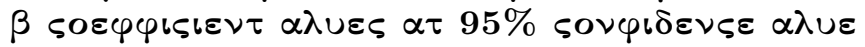




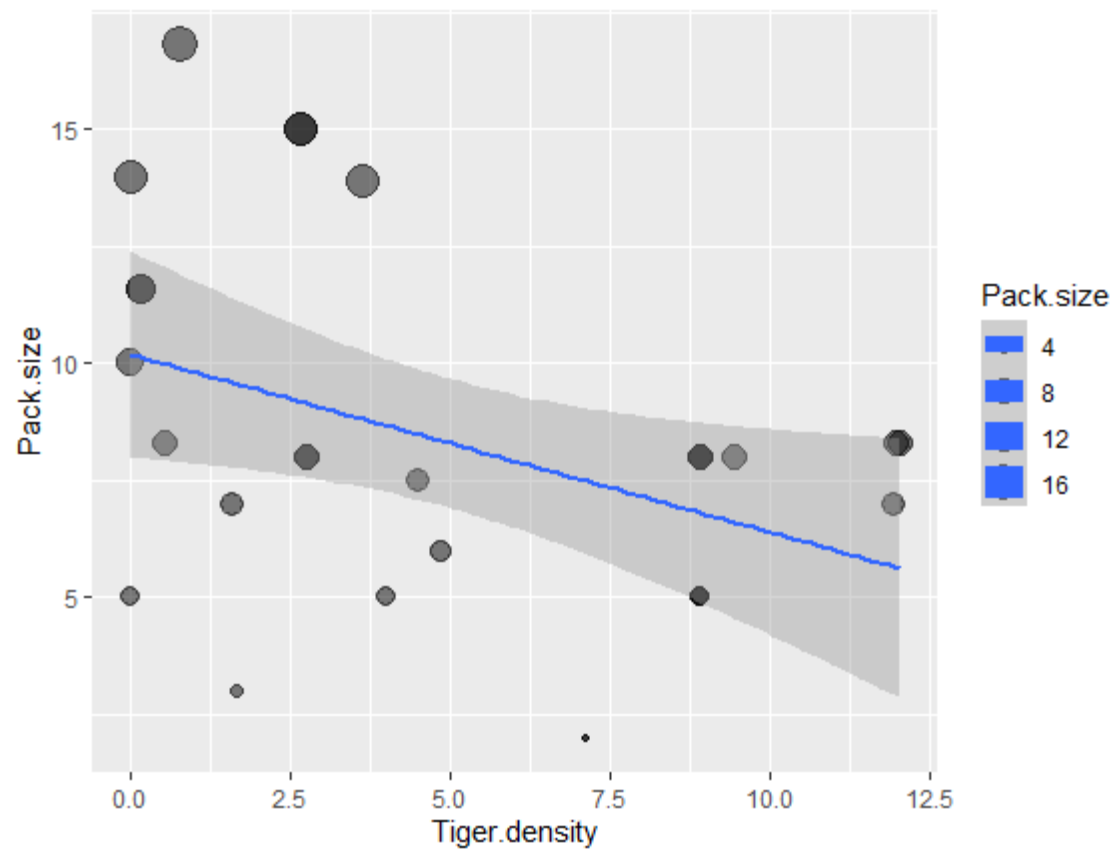

Figure 4. Dhole pack size in response to tiger density based on distribution wide assessment

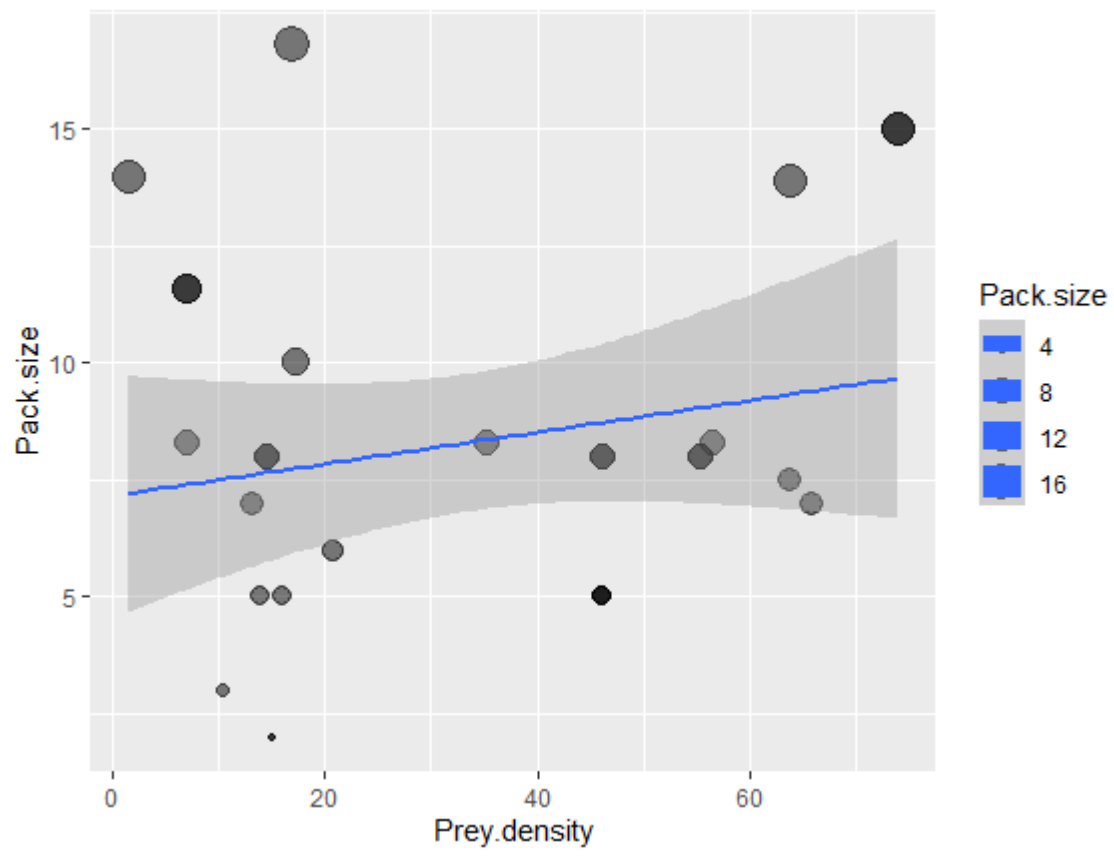

Figure 5. Dhole pack size in response to prey density based on distribution wide assessment 


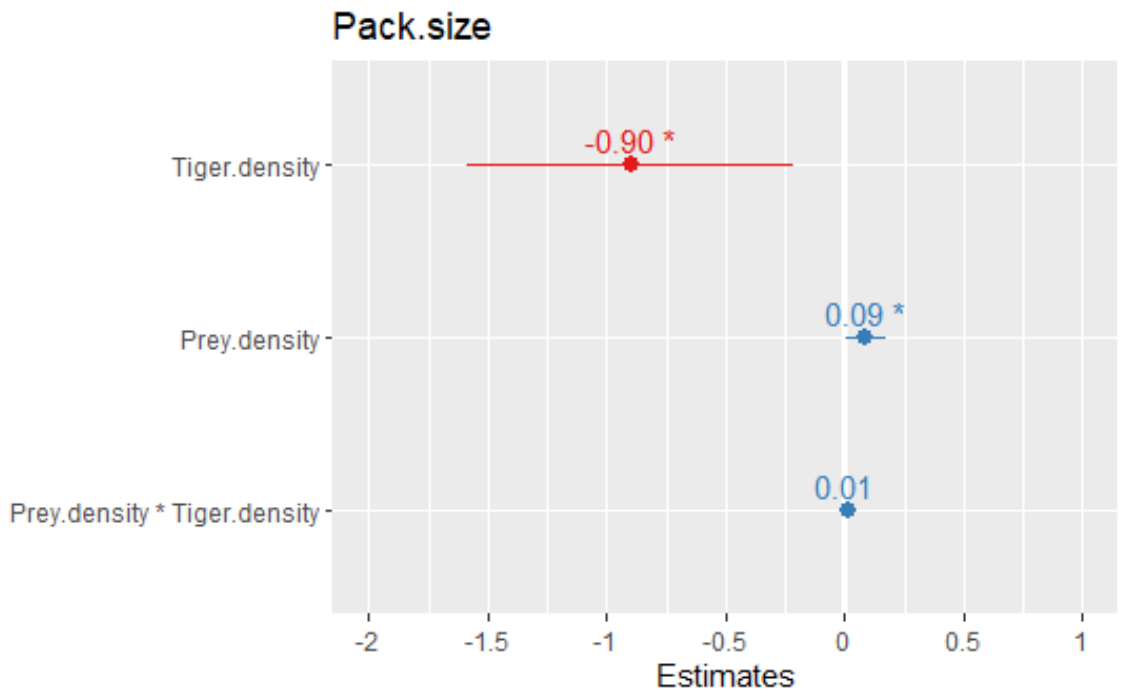

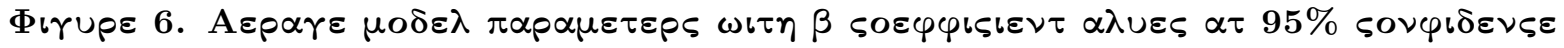 Discussion}

Apex predator actively harvests prey population and suppress mesopredator community structure through top-down mechanisms (Ripple et al., 2014). However, there is a dearth of evidence for subordinate predator suppression due to lack of such natural experiment study systems. We got an opportunity to understand the impact of a solitary apex predator on competitively inferior social predator in a natural experiment setup.

The Asiatic wild dog/ dhole is listed under "Endangered" category by IUCN, with about only 949-2215 mature individuals surviving globally. Indian subcontinent harbors majority of the viable dhole population (Kamler et al., 2015). However, the species has been exterminated from $60 \%$ of its past distributional range in India (Karanth et al., 2010) due to decline in prey base, habitat loss, human persecution and intra-guild competition (Hayward, Lyngdoh, \& Habib, 2014; kamler et al., 2015). In India, persistence of dholes is mostly confined to protected areas with infrequent presence records from secondary forests and agro-forest plantations (Srivathsa, Karanth, Kumar, \& Oli, 2019). These remnant habitat patches are also shared by other large carnivores, thereby limiting dhole population by lethal intra-guild interactions (Steinmetz, Seuaturien, \& Chutipong, 2013). Small size of PAs and lopsided conservation efforts can further result in overinflated apex carnivore densities and be detrimental for subordinate predators like dholes (Rayan \& Linkie, 2016; Kumar, Awasthi, Qureshi, \& Jhala, 2019). Therefore, to conserve the endangered dhole, it is crucial to understand its response to tigers, itself an endangered and flagship species. A holistic understanding of guild interactions would improve our ability to optimize ecological triage while conserving charismatic apex predators and mid-ranking predators.

In this study, we found that the pack size was reduced in higher tiger density areas. This might be due to the influence of interference competition wherein a narrower niche is available for dholes to occupy which limits their persistence. Studies from Africa also show a similar trend where pack sizes of African wild dogs were reduced in areas of higher lion densities (Groom, Lannas, \& Jackson, 2017). At high tiger density site (TATR) we also observed direct intraguild predation events i.e. tigers killing dholes $(n=5)$ however, no such events have been observed in NNTR, the low tiger density site. Similar events have been documented in African system by Creel and Creel (1996), where lions actively chase away dogs and in certain instances even kill them.

Conversely, in low tiger density area, larger pack size is indicative of a competitive release scenario (Groom, Lannas, \& Jackson, 2017). A similar trend has been observed in spotted hyena clan size and pack size of 
African wild dog due to reduced interspecific competition in a lion depleted system and easy availability of food subsidies (Periquet, Fritz, \& Revilla, 2014; Green, Farr, Holekamp, Strauss, \& Zipkin, 2019; Groom, Lannas, \& Jackson, 2017).

There was no significant difference between the individual prey densities at both studies, however, the higher density of a large-body size prey in NNTR is also interesting to note. This finding is in line with the idea that low numbers of apex predator lead to an increase in abundance of large-bodied prey in a system. The subordinate predators are limited by body-size and cannot target such large prey and this might be one of the possible explanations for our finding. Similar pattern is observed in study systems where wolf (Canis lupus ) populations are controlled (Burgar, Burton, \& Fisher, 2019) that not only causes coyote (Canis latrans ) abundance to increase but also leads to stable number of adults in caribou (Rangifer tarandus ) population since coyotes are size-limited and cannot take down larger individuals (Lewis, Gullage, Fifield, Jennings, \& Mahoney, 2017).

To examine whether reserve level patterns were concurrent with global scale, we did a distribution-wide assessment of pack size across dhole distributional range. We found support for our first two hypotheses, dhole pack size were positively associated with prey density and negatively associated with tiger densities. Statistically significant but moderate effect size reflects that the patterns were diffused at global scale. Patterns of subordinate predator response to apex predators numbers do not always mirror each other over temporal and spatial scales (Jachowski et al., 2020), pertaining to area specific ecological settings, anthropogenic disturbances, level of protection at reserve level and connectivity in the landscape at regional scale (Greenville, Wardle, Tamayo, \& Dickman, 2014; Newsome, \& Ripple, 2015). We did not find support for our third hypothesis, dhole pack size was not associated with high terrain ruggedness however, a low pack size has been reported from studies of high altitude and rugged terrain (Bashir, Bhattacharya, Poudyal, Roy, \& Sathyakumar, 2014; Lyngdoh, Gopi, Selvan, \& Habib, 2014).

Taken together, our reserve level and distribution wide assessment results are in support of the hypothesis that area specific ecological settings such as prey composition, abundance, and co-predator density are drivers of carnivore community structure, group size and behavior (M'soka, Creel, Becker, \& Droge, 2016). Patterns of this study also adhere to trends that have been observed in other long-term studies from Serengeti National Park, Ngorongoro Conservation Area and Selous Game Reserve, Tanzania, where the group size of subordinate predators are positively associated with availability of food resources and negatively associated with, apex predator numbers (Creel \& Creel, 1996; Creel \& Creel, 1998; Woodroffe \& Ginsberg, 1999; Pole, 2000; Périquet, Fritz, \& Revilla, 2015; Green, Farr, Holekamp, Strauss, \& Zipkin, 2019).

Tiger and dhole belong to the same carnivore guild because of similar diet spectrum (Hayward, Lyngdoh, \& Habib, 2014), and therefore their persistence in an area is linked to each other (Johnsingh,1992). Studies based on non-invasive sampling such as camera trapping and occupancy surveys suggest that carnivores adapt to mechanisms of niche partitioning, depending on resource availability to facilitate sympatry (Karanth et al, 2017). Very few studies have demonstrated that intense intra-guild competition result in reduced density and spatial displacement of the subordinate predators (Harihar, Pandav, \& Goyal, 2011; Mondal, Gupta, Bhattacharjee, Qureshi, \& Sankar, 2012; Steinmetz, Seuaturien, \& Chutipong, 2013). Our study provides a new direction in understanding how intra-guild competition can also potentially limit pack size of dhole.

Competition from dominant carnivores remains one of the major factors that drives densities of other sympatric carnivores in a system (Wrangham, Gittleman, \& Chapman, 1993). NNTR and TATR are a comparable natural experiment setup that allows us to study how these two endangered tropical carnivores interact and understand consequences of dominance shift. We suggest that the increased pack size of a social subordinate predator (dhole) is an outcome of low density of apex predator and availability of wider niche. The decision to form large packs as compared to small packs is going to be more advantageous to limit the growth of top predator. However, future long-term studies are suggested based on multiple pack-year data, disease prevalence, predation, kleptoparasitism events and recruitment rate of dholes, across a gradient of apex predator density would further validate our hypothesis. 


\section{Reference}

Linnell, J.D. and Strand, O., 2000. Interference interactions, co-existence and conservation of mammalian carnivores. Diversity and Distributions , 6 (4), pp.169-176. https://doi.org/10.1046/j.1472-4642.2000.00069.x

Ford, A.T. and Goheen, J.R., 2015. Trophic cascades by large carnivores: a case for strong inference and mechanism. Trends in Ecology $\&$ Evolution, 30 (12), pp.725-735. https://doi.org/10.1016/j.tree.2015.09.012

Palomares, F. and Caro, T.M., 1999. Interspecific killing among mammalian carnivores. The American Naturalist , 153 (5), pp.492-508. https://doi.org/10.1086/303189

Caro, T.M. and O'Doherty, G., 1999. On the use of surrogate species in conservation biology. Conservation biology , 13 (4), pp.805-814. https://doi.org/10.1046/j.1523-1739.1999.98338.x

Ritchie, E.G. and Johnson, C.N., 2009. Predator interactions, mesopredator release and biodiversity conservation. Ecology letters , 12 (9), pp.982-998. https://doi.org/10.1111/j.1461-0248.2009.01347.x

Case, T.J. and Gilpin, M.E., 1974. Interference competition and niche theory. Proceedings of the National Academy of Sciences , 71 (8), pp.3073-3077. https://doi.org/10.1073/pnas.71.8.3073

Macdonald DW. The ecology of carnivore social behaviour. Nature. 1983 Feb 3;301(5899):379-84.

Crooks, K.R. and Soule, M.E., 1999. Mesopredator release and avifaunal extinctions in a fragmented system. Nature , 400 (6744), pp.563-566. https://doi.org/10.1038/23028

Letnic, M., Ritchie, E.G. and Dickman, C.R., 2012. Top predators as biodiversity regulators: the dingo Canis lupus dingo as a case study. Biological Reviews , 87 (2), pp.390-413. https://doi.org/10.1111/j.1469185X.2011.00203.X

Vance, R.R., 1984. Interference competition and the coexistence of two competitors on a single limiting resource. Ecology , 65 (5), pp.1349-1357. https://doi.org/10.2307/1939115

Ordiz, A., Bischof, R. and Swenson, J.E., 2013. Saving large carnivores, but losing the apex predator?.BiologicalConservation , 168 ,pp.128-133. https://doi.org/10.1016/j.biocon.2013.09.024

Creel, S. and Creel, N.M., 1996. Limitation of African wild dogs by competition with larger carnivores. Conservation Biology , 10 (2), pp.526-538. https://doi.org/10.1046/j.1523-1739.1996.10020526.x

Durant, S.M., 2000. Living with the enemy: avoidance of hyenas and lions by cheetahs in the Serengeti. Behavioral ecology , 11 (6), pp.624-632. https://doi.org/10.1093/beheco/11.6.624

Durant, S.M., 1998. Competition refuges and coexistence: an example from Serengeti carnivores. Journal of Animal ecology , 67 (3), pp.370-386. https://doi.org/10.1046/j.1365-2656.1998.00202.x

Creel, S., 2001. Four factors modifying the effect of competition on carnivore population dynamics as illustrated by African wild dogs. Conservation Biology , 15 (1), pp.271-274. https://doi.org/10.1111/j.15231739.2001.99534.x

Greenville, A.C., Wardle, G.M., Tamayo, B. and Dickman, C.R., 2014. Bottom-up and top-down processes interact to modify intraguild interactions in resource-pulse environments. Oecologia , 175 (4), pp.1349-1358. https://doi.org/10.1007/s00442-014-2977-8

Newsome, T.M. and Ripple, W.J., 2015. Carnivore coexistence: trophic cascades. Science , 347 (6220), pp.383-383. DOI: 10.1126/science.347.6220.383-a

Swanson, A., Caro, T., Davies-Mostert, H., Mills, M.G., Macdonald, D.W., Borner, M., Masenga, E. and Packer, C., 2014. Cheetahs and wild dogs show contrasting patterns of suppression by lions. Journal of animal ecology , 83 (6), pp.1418-1427. https://doi.org/10.1111/1365-2656.12231

Periquet, S., Fritz, H. and Revilla, E., 2015. The Lion King and the Hyaena Queen: large carnivore interactions and coexistence. Biological reviews , 90 (4), pp.1197-1214. https://doi.org/10.1111/brv.12152 
Carbyn, L.N., Armbruster, H.J. and Mamo, C., 1994. The swift fox reintroduction program in Canada from 1983 to 1992. Restoration of endangered species, pp.247-271.

Clark, T.W., 1994. Restoration of the endangered black-footed ferret: a 20-year overview. Restoration of endangered species, pp.272-297.

Lindstrom, E.R., Brainerd, S.M., Helldin, J.O. and Overskaug, K., 1995, January. Pine marten—red fox interactions: a case of intraguild predation?. In Annales zoologici fennici (pp. 123-130). Finnish Zoological and Botanical Publishing Board.

Henke, S.E. and Bryant, F.C., 1999. Effects of coyote removal on the faunal community in western Texas. The Journal of Wildlife Management, pp.1066-1081.

Krofel, M., Giannatos, G., Ćirovič, D., Stoyanov, S. and Newsome, T.M., 2017. Golden jackal expansion in Europe: a case of mesopredator release triggered by continent-wide wolf persecution?. Hystrix: Italian journal of mammalogy, 28(1), pp.9-15. https://doi.org/10.4404/hystrix-28.1-11819

M'soka J, Creel S, Becker MS, Droge E. 2016 Spotted hyaena survival and density in a lion depleted ecosystem: The effects of prey availability, humans and competition between large carnivores in African savannahs. Biol. Conserv. 201, 348-355. https://doi:10.1016/j.biocon.2016.07.011

Clutton-Brock, T.H., Gaynor, D., McIlrath, G.M., Maccoll, A.D.C., Kansky, R., Chadwick, P., Manser, M., Skinner, J.D. and Brotherton, P.N.M., 1999. Predation, group size and mortality in a cooperative mongoose, Suricata suricatta. Journal of Animal Ecology, 68 (4), pp.672-683. https:// doi:10.1046/j.13652656.1999.00317x

Steinmetz, R., Seuaturien, N. and Chutipong, W., 2013. Tigers, leopards, and dholes in a half-empty forest: assessing species interactions in a guild of threatened carnivores. Biological conservation, 163 , pp.68-78. https://doi.org/10.1016/j.biocon.2012.12.016

Acharya, B.B., 2007. The ecology of the dhole or Asiatic wild dog (Cuon alpinus) in Pench Tiger Reserve, Madhya Pradesh. Unpublished PhD Dissertation. Saurashtra University, Rajkot, India .

Johnsingh, A.J.T., 1992. Prey selection in three large sympatric carnivores in Bandipur. Mammalia , 56 (4), pp.517-526. https://doi.org/10.1515/mamm.1992.56.4.517

Karanth, K.U. and Sunquist, M.E., 2000. Behavioural correlates of predation by tiger (Panthera tigris), leopard (Panthera pardus) and dhole (Cuon alpinus) in Nagarahole, India. Journal of Zoology , 250 (2), pp.255-265. https://doi.org/10.1111/j.1469-7998.2000.tb01076.x

Wang, S.W. and Macdonald, D.W., 2009. Feeding habits and niche partitioning in a predator guild composed of tigers, leopards and dholes in a temperate ecosystem in central Bhutan. Journal of Zoology , 277 (4), pp.275-283. https://doi.org/10.1111/j.1469-7998.2008.00537.x

Wegge, P., Odden, M., Pokharel, C.P. and Storaas, T., 2009. Predator-prey relationships and responses of ungulates and their predators to the establishment of protected areas: a case study of tigers, leopards and their prey in Bardia National Park, Nepal. Biological Conservation , 142 (1), pp.189-202. https://doi.org/10.1016/j.biocon.2008.10.020

Rayan, D.M. and Linkie, M., 2016. Managing conservation flagship species in competition: Tiger, leopard and dhole in Malaysia. Biological Conservation , 204 , pp.360-366. https://doi.org/10.1016/j.biocon.2016.11.009

Karanth, K.U. and Sunquist, M.E., 1995. Prey selection by tiger, leopard and dhole in tropical forests. Journal of Animal Ecology, pp.439-450. https://doi.org/10.1016/j.biocon.2016.11.009

Karanth, K.U., Srivathsa, A., Vasudev, D., Puri, M., Parameshwaran, R. and Kumar, N.S., 2017. Spatio-temporal interactions facilitate large carnivore sympatry across a resource 
gradient. Proceedings of the Royal Society B: Biological Sciences , 284 (1848), p.20161860. https://doi.org/10.1016/j.biocon.2016.11.009doi:10.1098/rspb.2016.1860

Rasphone, A., Kéry, M., Kamler, J.F. and Macdonald, D.W., 2019. Documenting the demise of tiger and leopard, and the status of other carnivores and prey, in Lao PDR's most prized protected area: Nam Et-Phou Louey. Global Ecology and Conservation, 20 , p.e00766. https://doi.org/10.1016/j.gecco.2019.e00766

Fernández-Gil, A., Quevedo, M., Barrientos, L.M., Nuño, A., Naves, J., de Gabriel, M., Ordiz, A. and Revilla, E., 2020. Pack size in humanized landscapes: the Iberian wolf population. Wildlife Biology , 2020 (2). https://doi.org/10.2981/wlb.00594

Green, D.S., Farr, M.T., Holekamp, K.E., Strauss, E.D. and Zipkin, E.F., 2019. Can hyena behaviour provide information on population trends of sympatric carnivores?. Philosophical Transactions of the Royal Society B , 374 (1781), p.20180052. https://doi.org/10.1016/j.biocon.2016.11.009doi:10.1098/rstb.2018.0052

Markham, A.C., Gesquiere, L.R., Alberts, S.C. and Altmann, J., 2015. Optimal group size in a highly social mammal. Proceedings of the National Academy of Sciences , 112 (48), pp.14882-14887. https://doi.org/10.1016/j.biocon.2016.11.009

Gusset, M. and Macdonald, D.W., 2010. Group size effects in cooperatively breeding African wild dogs. Animal Behaviour, 79 (2), pp.425-428. https://doi:10.1016/j.anbehav.2009.11.021

White, P.J. and Garrott, R.A., 2005. Northern Yellowstone elk after wolf restoration. Wildlife Society Bulletin , 33 (3), pp.942-955. https://doi.org/10.2193/0091-7648(2005)33[942:NYEAWR]2.0.CO;2

Rodgers, W.A. and Panwar, S.H., 1988. Biogeographical classification of India New Forest. Dehra Dun, India

Champion, H.G. and Seth, S.K., 1968. A revised survey of the forest types of India. Manager of publications.

Dhanwatey, H.S., Crawford, J.C., Abade, L.A., Dhanwatey, P.H., Nielsen, C.K. and Sillero-Zubiri, C., 2013. Large carnivore attacks on humans in central India: a case study from the Tadoba-Andhari Tiger Reserve. Oryx , 47 (2), pp.221-227. https://doi:10.1017/S0030605311001803

Modi, S., Habib, B., Ghaskadbi, P., Nigam, P. and Mondol, S., 2019. Standardization and validation of a panel of cross-species microsatellites to individually identify the Asiatic wild dog (Cuon alpinus). PeerJ, 7, p.e7453. https://doi.org/10.7717/peerj.7453

Stansbury, C.R., Ausband, D.E., Zager, P., Mack, C.M., Miller, C.R., Pennell, M.W. and Waits, L.P., 2014. A long-term population monitoring approach for a wide-ranging carnivore: noninvasive genetic sampling of gray wolf rendezvous sites in Idaho, USA. The Journal of Wildlife Management, 78(6), pp.1040-1049. https://doi.org/10.1002/jwmg.736

Grassman, L.I., Tewes, M.E., Silvy, N.J. and Kreetiyutanont, K., 2005. Spatial ecology and diet of the dhole Cuon alpinus (Canidae, Carnivora) in north central Thailand. Mammalia, 69(1), pp.11-20. https://doi.org/10.1515/mamm.2005.002

Buckland, S.T., Anderson, D.R., Burnham, K.P., Laake, J.L., Borchers, D.L. and Thomas, L., 2001. Introduction to distance sampling: estimating abundance of biological populations.

Thomas, L., Buckland, S.T., Rexstad, E.A., Laake, J.L., Strindberg, S., Hedley, S.L., Bishop, J.R., Marques, T.A. and Burnham, K.P., 2010. Distance software: design and analysis of distance sampling surveys for estimating population size. Journal of Applied Ecology , 47 (1), pp.5-14. https://doi:10.1111/j.13652664.2009.01737.x

Karanth, K.U. and Nichols, J.D., 1998. Estimation of tiger densities in India using photographic captures and recaptures. Ecology, 79 (8), pp.2852-2862. 
Pollock, K.H., Nichols, J.D., Brownie, C. and Hines, J.E., 1990. Statistical inference for capture-recapture experiments. Wildlife monographs, pp.3-97.

Borchers, D.L. and Efford, M.G., 2008. Spatially explicit maximum likelihood methods for capture-recapture studies. Biometrics , 64 (2), pp.377-385. https://doi:10.1111/j.1541-0420.2007.00927.x

Efford M, Efford MM. 2019 Package 'secr'.

Srivathsa, A., Sharma, S. and Oli, M.K., 2020. Every dog has its prey: Range-wide assessment of links between diet patterns, livestock depredation and human interactions for an endangered carnivore. Science of The Total Environment, 714 , p.136798. https://doi.org/10.1016/j.scitotenv.2020.136798

Handcock, M.S. and Gile, K.J., 2011. Comment: On the concept of snowball sampling. Sociological Methodology , 41 (1), pp.367-371. https://doi.org/10.1111\%2Fj.1467-9531.2011.01243.x

Gorelick, N., Hancher, M., Dixon, M., Ilyushchenko, S., Thau, D. and Moore, R., 2017. Google Earth Engine: Planetary-scale geospatial analysis for everyone. Remote sensing of Environment, 202 , pp.18-27. https://doi.org/10.1016/j.rse.2017.06.031

Ripple, W.J., Estes, J.A., Beschta, R.L., Wilmers, C.C., Ritchie, E.G., Hebblewhite, M., Berger, J., Elmhagen, B., Letnic, M., Nelson, M.P. and Schmitz, O.J., 2014. Status and ecological effects of the world's largest carnivores. Science, 343 (6167). DOI:10.1126/science.1241484

Kamler, J.F., Songsasen, N., Jenks, K., Srivathsa, A., Sheng, L. and Kunkel, K., 2015. Cuon alpinus. The IUCN Red List of Threatened Species 2015: e. T5953A72477893.

Karanth, K.K., Nichols, J.D., Karanth, K.U., Hines, J.E. and Christensen Jr, N.L., 2010. The shrinking ark: patterns of large mammal extinctions in India. Proceedings of the Royal Society B: Biological Sciences , 277 (1690), pp.1971-1979. https://doi.org/10.1098/rspb.2010.0171

Hayward, M.W., Lyngdoh, S. and Habib, B., 2014. Diet and prey preferences of dholes (C uon alpinus): dietary competition within A sia's apex predator guild. Journal of Zoology , 294 (4), pp.255-266. https://doi.org/10.1111/jzo.12171

Srivathsa, A., Karanth, K.U., Kumar, N.S. and Oli, M.K., 2019. Insights from distribution dynamics inform strategies to conserve a dhole Cuon alpinus metapopulation in India. Scientific reports , 9 (1), pp.1-12. https://doi.org/10.1038/s41598-019-39293-0

Kumar, U., Awasthi, N., Qureshi, Q. and Jhala, Y., 2019. Do conservation strategies that increase tiger populations have consequences for other wild carnivores like leopards?. Scientific reports , 9 (1), pp.1-8. https://doi.org/10.1038/s41598-019-51213-w

Groom, R.J., Lannas, K. and Jackson, C.R., 2017. The impact of lions on the demography and ecology of endangered African wild dogs. Animal Conservation, 20 (4), pp.382-390. https://doi.org/10.1111/acv.12328

Burgar, J.M., Burton, A.C. and Fisher, J.T., 2019. The importance of considering multiple interacting species for conservation of species at risk. Conservation Biology , 33 (3), pp.709-715. https://doi.org/10.1111/cobi.13233

Lewis, K.P., Gullage, S.E., Fifield, D.A., Jennings, D.H. and Mahoney, S.P., 2017. Manipulations of black bear and coyote affect caribou calf survival. The Journal of Wildlife Management, 81(1), pp.122-132. https://doi.org/10.1002/jwmg.21174

Jachowski, D.S., Butler, A., Eng, Robin Y.Y., Gigliotti, L., Harris, S., and Williams, A., 2020. Identifying mesopredator release in multi-predator systems: a review of evidence from North America. Mammal Review, https://doi.org/10.1111/mam.12207

Bashir, T.A.W.Q.I.R., Bhattacharya, T., Poudyal, K., Roy, M. and Sathyakumar, S., 2014. Precarious status of the Endangered dhole Cuon alpinus in the high elevation Eastern Himalayan habitats of Khangchendzonga 
Biosphere Reserve, Sikkim, India. Oryx, 48(1), pp.125-132. https://doi.org/10.1017/S003060531200049X

Lyngdoh, S., Gopi, G.V., Selvan, K.M. and Habib, B., 2014. Effect of interactions among ethnic communities, livestock and wild dogs (Cuon alpinus) in Arunachal Pradesh, India. European Journal of Wildlife Research, 60(5), pp.771-780. https://doi.org/10.1007/s10344-014-0846-8

Harihar, A., Pandav, B. and Goyal, S.P., 2011. Responses of leopard Panthera pardus to the recovery of a tiger Panthera tigris population. Journal of Applied Ecology , 48 (3), pp.806-814. https://doi.org/10.1111/j.1365-2664.2011.01981.x

Mondal, K., Gupta, S., Bhattacharjee, S., Qureshi, Q. and Sankar, K., 2012. Response of leopards to re-introduced tigers in Sariska Tiger Reserve, Western India. International Journal of Biodiversity and Conservation , 4 (5), pp.228-236. https://doi.org/10.5897/IJBC12.014

Wrangham, R.W., Gittleman, J.L. and Chapman, C.A., 1993. Constraints on group size in primates and carnivores: population density and day-range as assays of exploitation competition. Behavioral ecology and Sociobiology , 32 (3), pp.199-209. https://doi.org/10.1007/BF00173778

Table 1. Individual density of various prey species from NNTR and TATR, Maharashtra, India

\begin{tabular}{lllll}
\hline Prey Species & $\begin{array}{l}\text { NNTR (Individual } \\
\text { density and SE) }\end{array}$ & Group size & $\begin{array}{l}\text { TATR (Individual } \\
\text { density and SE) }\end{array}$ & Group size \\
\hline Chital & $4.61 \pm 1.2$ & 5.02 & $5.10 \pm 1.22$ & 5.13 \\
Sambar & $1.41 \pm 0.32$ & 1.88 & $4.68 \pm 0.76$ & 2.25 \\
Nilgai & $1.99 \pm 0.35$ & 1.81 & $1.09 \pm 0.36$ & 2.50 \\
Wild pig & $3.12 \pm 1.11$ & 6.32 & $5.42 \pm 2.08$ & 7.22 \\
Gaur & $5.21 \pm 1.41$ & 5.98 & $2.03 \pm 1.15$ & 2.35 \\
Barking deer & $0.6 \pm 0.2$ & 1 & $0.96 \pm 0.23$ & 1.37 \\
\hline
\end{tabular}

Table 2. Model selection Following information criterion

\begin{tabular}{|c|c|c|c|c|c|}
\hline Model ID & Models & (Intercept) & Prey.density & Reserve.size & $\mathrm{Te}$ \\
\hline $\bmod 3$ & Tiger density + Prey density & 8.385 & 0.106 & NA & $\mathrm{N} A$ \\
\hline $\bmod 2$ & Tiger density $*$ Prey density & 9.450 & 0.066 & NA & $\mathrm{N} A$ \\
\hline $\bmod 1$ & Tiger density + Prey density + PA size + Terrain ruggedness & 10.793 & 0.102 & -0.085 & -0 . \\
\hline $\bmod 9$ & Tiger density & 10.191 & NA & NA & NA \\
\hline $\bmod 4$ & Tiger density + Terrain ruggedness & 12.986 & NA & NA & $\mathrm{N}$ \\
\hline $\bmod 6$ & Tiger density + PA size & 15.950 & NA & -1.878 & -1. \\
\hline $\bmod 0$ & Null model & 8.286 & NA & NA & $\mathrm{N}$ \\
\hline $\bmod 10$ & Prey density & 7.157 & 0.034 & NA & NA \\
\hline $\bmod 5$ & Prey density + Terrain ruggedness & 9.296 & 0.031 & NA & $\mathrm{N} A$ \\
\hline $\bmod 7$ & Prey density + PA size & 3.526 & 0.044 & 1.146 & 1.1 \\
\hline $\bmod 8$ & PA size + Terrain ruggedness & 11.306 & NA & -0.228 & -0 . \\
\hline
\end{tabular}

Table 3. Model selection Following $\mathrm{AIC}_{\mathrm{C}}$, Royall's 1/8 rule for strength of evidence, and $\mathbf{9 5 \%}$ cumulative weight criteria 


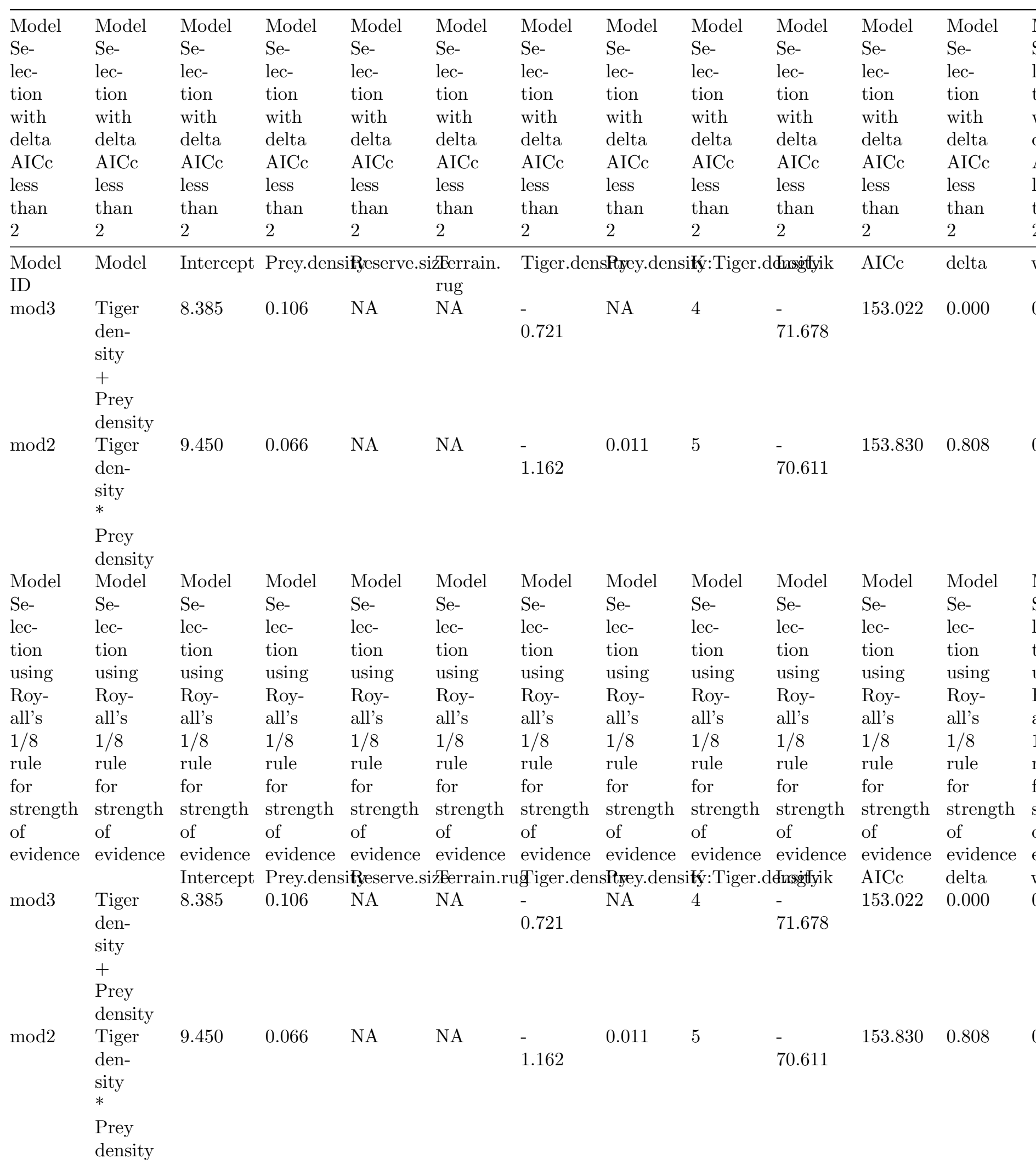




\begin{tabular}{|c|c|c|c|c|c|c|c|c|c|c|c|}
\hline $\begin{array}{l}\text { Model } \\
\text { Se- } \\
\text { lec- } \\
\text { tion } \\
\text { with } \\
\text { delta } \\
\text { AICc } \\
\text { less } \\
\text { than } \\
2\end{array}$ & $\begin{array}{l}\text { Model } \\
\text { Se- } \\
\text { lec- } \\
\text { tion } \\
\text { with } \\
\text { delta } \\
\text { AICc } \\
\text { less } \\
\text { than } \\
2\end{array}$ & $\begin{array}{l}\text { Model } \\
\text { Se- } \\
\text { lec- } \\
\text { tion } \\
\text { with } \\
\text { delta } \\
\text { AICc } \\
\text { less } \\
\text { than } \\
2\end{array}$ & $\begin{array}{l}\text { Model } \\
\text { Se- } \\
\text { lec- } \\
\text { tion } \\
\text { with } \\
\text { delta } \\
\text { AICc } \\
\text { less } \\
\text { than } \\
2\end{array}$ & $\begin{array}{l}\text { Model } \\
\text { Se- } \\
\text { lec- } \\
\text { tion } \\
\text { with } \\
\text { delta } \\
\text { AICc } \\
\text { less } \\
\text { than } \\
2\end{array}$ & $\begin{array}{l}\text { Model } \\
\text { Se- } \\
\text { lec- } \\
\text { tion } \\
\text { with } \\
\text { delta } \\
\text { AICc } \\
\text { less } \\
\text { than } \\
2\end{array}$ & $\begin{array}{l}\text { Model } \\
\text { Se- } \\
\text { lec- } \\
\text { tion } \\
\text { with } \\
\text { delta } \\
\text { AICc } \\
\text { less } \\
\text { than } \\
2\end{array}$ & $\begin{array}{l}\text { Model } \\
\text { Se- } \\
\text { lec- } \\
\text { tion } \\
\text { with } \\
\text { delta } \\
\text { AICc } \\
\text { less } \\
\text { than } \\
2\end{array}$ & $\begin{array}{l}\text { Model } \\
\text { Se- } \\
\text { lec- } \\
\text { tion } \\
\text { with } \\
\text { delta } \\
\text { AICc } \\
\text { less } \\
\text { than } \\
2\end{array}$ & $\begin{array}{l}\text { Model } \\
\text { Se- } \\
\text { lec- } \\
\text { tion } \\
\text { with } \\
\text { delta } \\
\text { AICc } \\
\text { less } \\
\text { than } \\
2\end{array}$ & $\begin{array}{l}\text { Model } \\
\text { Se- } \\
\text { lec- } \\
\text { tion } \\
\text { with } \\
\text { delta } \\
\text { AICc } \\
\text { less } \\
\text { than } \\
2\end{array}$ & $\begin{array}{l}\text { Model } \\
\text { Se- } \\
\text { lec- } \\
\text { tion } \\
\text { with } \\
\text { delta } \\
\text { AICc } \\
\text { less } \\
\text { than } \\
2\end{array}$ \\
\hline $\begin{array}{l}\text { Model } \\
\text { selec- } \\
\text { tion } \\
\text { based } \\
\text { on } \\
95 \% \\
\text { cu- } \\
\text { mu- } \\
\text { la- } \\
\text { tive } \\
\text { weight } \\
\text { criteria }\end{array}$ & $\begin{array}{l}\text { Model } \\
\text { selec- } \\
\text { tion } \\
\text { based } \\
\text { on } \\
95 \% \\
\text { cu- } \\
\text { mu- } \\
\text { la- } \\
\text { tive } \\
\text { weight } \\
\text { criteria }\end{array}$ & $\begin{array}{l}\text { Model } \\
\text { selec- } \\
\text { tion } \\
\text { based } \\
\text { on } \\
95 \% \\
\text { cu- } \\
\text { mu- } \\
\text { la- } \\
\text { tive } \\
\text { weight } \\
\text { criteria } \\
\text { Intercept }\end{array}$ & $\begin{array}{l}\text { Model } \\
\text { selec- } \\
\text { tion } \\
\text { based } \\
\text { on } \\
95 \% \\
\text { cu- } \\
\text { mu- } \\
\text { la- } \\
\text { tive } \\
\text { weight } \\
\text { criteria } \\
\text { Prey.densi }\end{array}$ & $\begin{array}{l}\text { Model } \\
\text { selec- } \\
\text { tion } \\
\text { based } \\
\text { on } \\
95 \% \\
\text { cu- } \\
\text { mu- } \\
\text { la- } \\
\text { tive } \\
\text { weight } \\
\text { criteria } \\
\text { iRyeserve.s }\end{array}$ & $\begin{array}{l}\text { Model } \\
\text { selec- } \\
\text { tion } \\
\text { based } \\
\text { on } \\
95 \% \\
\text { cu- } \\
\text { mu- } \\
\text { la- } \\
\text { tive } \\
\text { weight } \\
\text { criteria } \\
\text { izberrain.rl }\end{array}$ & $\begin{array}{l}\text { Model } \\
\text { selec- } \\
\text { tion } \\
\text { based } \\
\text { on } \\
95 \% \\
\text { cu- } \\
\text { mu- } \\
\text { la- } \\
\text { tive } \\
\text { weight } \\
\text { criteria } \\
\text { ugiger.den }\end{array}$ & $\begin{array}{l}\text { Model } \\
\text { selec- } \\
\text { tion } \\
\text { based } \\
\text { on } \\
95 \% \\
\text { cu- } \\
\text { mu- } \\
\text { la- } \\
\text { tive } \\
\text { weight } \\
\text { criteria } \\
\text { sPtyey.dens }\end{array}$ & $\begin{array}{l}\text { Model } \\
\text { selec- } \\
\text { tion } \\
\text { based } \\
\text { on } \\
95 \% \\
\text { cu- } \\
\text { mu- } \\
\text { la- } \\
\text { tive } \\
\text { weight } \\
\text { criteria } \\
\text { sity:Tiger.c }\end{array}$ & $\begin{array}{l}\text { Model } \\
\text { selec- } \\
\text { tion } \\
\text { based } \\
\text { on } \\
95 \% \\
\text { cu- } \\
\text { mu- } \\
\text { la- } \\
\text { tive } \\
\text { weight } \\
\text { criteria } \\
\text { densigtyik }\end{array}$ & $\begin{array}{l}\text { Model } \\
\text { selec- } \\
\text { tion } \\
\text { based } \\
\text { on } \\
95 \% \\
\text { cu- } \\
\text { mu- } \\
\text { la- } \\
\text { tive } \\
\text { weight } \\
\text { criteria } \\
\text { AICc }\end{array}$ & $\begin{array}{l}\text { Model } \\
\text { selec- } \\
\text { tion } \\
\text { based } \\
\text { on } \\
95 \% \\
\text { cu- } \\
\text { mu- } \\
\text { la- } \\
\text { tive } \\
\text { weight } \\
\text { criteria } \\
\text { delta }\end{array}$ \\
\hline $\bmod 3$ & $\begin{array}{l}\text { Tiger } \\
\text { den- } \\
\text { sity } \\
+ \\
\text { Prey } \\
\text { density }\end{array}$ & 8.385 & 0.106 & $\mathrm{NA}$ & NA & - & $\mathrm{NA}$ & 4 & - 71.68 & 153.02 & 0.00 \\
\hline $\bmod 2$ & $\begin{array}{l}\text { Tiger } \\
\text { den- } \\
\text { sity } \\
* \\
\text { Prey } \\
\text { density }\end{array}$ & 9.450 & 0.066 & NA & NA & $\begin{array}{l}- \\
1.162\end{array}$ & 0.011 & 5 & $\begin{array}{l}- \\
70.611\end{array}$ & 153.83 & 0.81 \\
\hline
\end{tabular}

Table 4. Model averaging output for all variables present in the top model selection

\begin{tabular}{|c|c|c|}
\hline & Estimate & Std. E \\
\hline Intercept & 8.811 & 1.248 \\
\hline Tiger.denisty & -0.897 & 0.340 \\
\hline Prey.density & 0.090 & 0.040 \\
\hline Prey.density*Tiger density & 0.011 & 0.008 \\
\hline 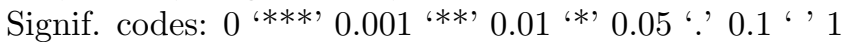 & 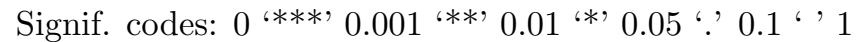 & Signif. \\
\hline
\end{tabular}

\section{Figure legend:}

Figure 1. Map showing Tadoba Andhari Tiger Reserve and Navegaon NagziraTiger Reserve in Eastern 
Vidarbha Landscape. Inset showing study area location in the map of India.

Figure 2. Comparison of dhole pack size from TATR and NNTR Figure 3. Showing all the significant and non-significant predictor variables with $\beta$ coefficient values at $95 \%$ confidence value Figure 4 . Dhole pack size in response to tiger density based on distribution wide assessment Figure 5. Dhole pack size in response to prey density based on distribution wide assessment

Figure 6. Average model parameters with $\beta$ coefficient values at $95 \%$ confidenc

\section{Data Accessibilty Statement}

All data is submitted alongwith manuscript in the form of supplementary material.

\section{Competing Interests Statement}

We have no competing interests.

\section{Author Contributions section}

B.H., P.N., A.B., and P.G. conceived the ideas; B.H., A.B., and P.G. and designed the study; A.B. and P.G. collected the data; A.B. and P.G. analyzed the data; A.B. and B.H. led the writing of the manuscript. B.H., P.N., A.B., and P.G. approved the final draft.

\section{Acknowledgements}

This study was funded by Wildlife Institute India, M.Sc. program fund and Maharashtra Forest Department,D-22(8)/WL/Reseach/CT-722/(12-13)/2934/2013. We thank Dean and Director, Wildlife Institute of India for institutional support. We thank the Chief wildlife Warden and Chief Conservator of Forest, Tadoba Andhari Tiger Reserve and Nawegaon Nagzira Tiger Reserve, Maharashtra State, for granting permission and facilitation of the study. We thank Nucharin Songsassen for her data inputs. We thank Nilanjan Chatterjee and Nakul Markandey for their help with GIS work. We thank Naman Goyal, Kumar Ankit and Akanksha Saxena for giving valuable inputs to improve the manuscript. 